\title{
AKTIVÍTÁs, SZABADIDŐSPORT
}

\section{Szerzők:}

Kinczel Antonia

Debreceni Egyetem (Magyarország)

Müller Anetta (PhD.)

Debreceni Egyetem (Magyarország)

Első szerző e-mail címe:

antokincz@gmail.com

Kinczel, A.; Müller A. (2020). Aktivitás, szabadidősport. Különleges Bánásmód, 6. (2). 49-58.

DOI $\underline{10.18458 / K B .2020 .2 .49}$

\section{Absztrakt}

Háttér: Jelenlegi életünkben a mozgásszegény, ülő életmód egyre inkább előtérbe kerül. Szabadidőnkben egyaránt megjelennek a passzív és aktív rekreációs trendek és tevékenységek. Az aktív mozgás és a prevenció szempontjából a szabadidős sportnak a szerepe egyre inkább felértékelődik az egészségtudatos fogyasztók körében. Több kutatás is bizonyította, hogy a rendszeres szabadidős sport projektív tényezőt képez számos életmódfüggő betegséggel szemben, így a prevenció egyik kiváló eszköze. Módszer: Vizsgálatunk kérdőívvel vizsgálta a romániai és magyarországi lakosok szabadidős szokásait, a sportban való aktivitásukat, az aktív rekreációs tevékenységekhez való hozzáállásukat, az új módszerekhez való nyitottságukat. A kapott eredményeket SPSS szoftver segítségével elemeztük. Eredmények: Az eredmények azt támasztják alá, hogy a passzív szabadidős tevékenységek (Tv nézés, zenehallgatás, olvasás, internetezés) népszerủek az emberek életében, és a legtöbben üló életmódot élnek. Azok az emberek, akik szabadidejükben sportolnak több pozitív hatást is észrevettek már magukon. A válaszadók 80-90\%-a nyitott lenne az új módszerekre, szívesen venne részt a munkahelyen/iskolában/egyetemen sportos rendezvényeken.

Kulcsszavak: aktív életmód, szabadidősport, prevenció

Diszciplína: gazdaságtudomány, szociológia

\section{Abstract}

\section{ACTIVITY, LEISURE SPORTS}

Nowadays sedentary lifestyle is at the forefront. In our spare time, both passive and active recreational trends and activities appear. The role of leisure sports is getting more and more appreciated among health-conscious consumers. Several studies proved that regular sports activities are projective factors against lifestyle-dependent diseases, so they are excellent means of prevention. Methods: Our study examined the leisure habits of Romanian and Hungarian residents, their activity in sport, their attitude towards active recreation activities, and their openness to new methods. The results were analyzed by using SPSS software. Results: The results underline that passive leisure activities (watching television, listening to music, reading, surfing the internet) are popular in people's lives, although most people live a sedentary lifestyle. People, who exercise in their free time have noticed a number of positive effects on themselves. $80-90 \%$ of respondents interested in new methods and would like to take part in sports events at work, at school, or at university.

Keywords: active lifestyle, leisure sports, prevention

Disciplines: economics, sociology 
Olyan világban élünk, ahol az emberek életét a teljesítmény és munkakényszer jellemzi (Dajnoki és Héder, 2017; Dajnoki et al, 2018; Héder et al., 2018). Már fiatalkorban számos olyan betegség figyelhetô meg, mint például a stressz, a szorongás, az obesitas vagy különböző tartáshibák és deformitások, amelyeket a szabadidősport növelésével csökkenteni tudnánk. A szabadidősportnak rengeteg pozitív tulajdonsága van, amelyet már több hazai (Juhász et. al., 2015, Müller és Bácsné, 2018, Simon et. al., 2018; Lenéné et. al., 2018) és nemzetközi (Dobay et. al., 2017, Bendíková et. al., 2018) szakirodalom is igazolt. A sport rengeteg dologra megtanít, mint például a kitartás, az önfeláldozás, a sikerek és kudarcélmények feldolgozása, a fáradtságtűrés, a reális önértékelés, és a tolerancia ugyanakkor fejleszti az akaraterôt, a szocializációt, a társas kapcsolatok alakulását, a bátorságot. Aktív testmozgással csökkenteni lehetne számos betegség későbbi kialakulását (Biró, 2018). Sokan halnak meg szívés érrendszeri megbetegedésekben, daganatos megbetegedésekben, korai koszorúér megbetegedésben, öngyilkosságban. A sport által megelőzhetők lennének a daganatos betegségek kialakulása, továbbá jellemzően kevesebben dohányoznak azok közül akik sportolnak, így a dohányosok száma is csökkenthetô lenne. Gyermekkorban elősegíti a szellemi és testi fejlődést. Ha kialakul a sport iránti szeretet, akkor felnőttkorban is sportolni fog a felnőtt gyermek, így egy sokkal egészségesebb életmódot fog élni.

$\mathrm{Az}$ emberek tisztában vannak a sport pozitív hatásaival, mégis inkább szabadidejüket a passzív rekreációs tevékenységekre fordítják (Horkai et al., 2018a). Mivel az emberek többsége nagyon leterhelt, így jellemzően már nincs kedve, motivációja az embernek egy hosszú, nehéz nap után a sportra. A sportolási szokásokat Fenyves et al. (2019a,b) vizsgálta egyetemi hallgatók körében. A gyermekek körében a telefon, internet világa egy idő után annyira leláncolja őket, hogy egyre kevesebb idôt töltenek a szabadban, kevesebbet mozognak, amellyel párhuzamosan a személyiségük is negatív irányba változhat. A szabadidő eltöltési szokásokat vizsgáló kutatások felhívják a figyelmet azokra a trendekre, melyek a szabadidős fogyasztást befolyásolják (Gödény et al., 2018, Horkai et al., 2018b; Fenyves et al, 2018; Bácsné et al, 2018a ).
A rekreációban még mindig erősen dominálnak a passzív szabadidős (Tv nézés, olvasás, internetezés, zenehallgatás) tevékenységek (Murányi, 2010), melyet a kutatásunk is megerősít.

Ha növelni tudjuk az emberek aktív testmozgását, illetve annak szintjét, akkor számos megbetegedés megelôzhető lenne. Nagy gond az egészségnevelésben, hogy a betegséget vagy netán a komoly egészségkárosodás (Dajnoki, 2012, 2014a, 2014b) veszélyét, az emberek nem veszik észre, nem törődnek vele, amikor még leginkább tehetnének valamit, amikor még nem késő életmódot változtatni (Buda, 1994). Olyan társadalmat kell kialakítanunk, amely tudatosan sportol, és odafigyel az egészségére.

\section{Anyag és módszer}

A szabadidő eltöltés vizsgálatára kérdőíves kutatást terveztünk, amelyben a vizsgálatban részt vevő személyek szabadidős preferencia-rendszerére voltunk kíváncsiak. A rekreációs szokások területén az aktív és passzív tevékenységi formák gyakoriságát is vizsgáltuk, továbbá azt, hogy milyen pozitív változást éreztek sport után, milyen témában szeretnének fejlődni. Rákérdeztünk arra is, hogyan viszonyulnának ha a munkahelyen/iskolában/egyetemen több lenne a sportolási lehetőség.

A kitöltők közül 344 fő $(67,6 \%)$ nő és 165 fó (32,\%) férfi válaszadó volt. Lakóhely szerint két csoportba oszthatók a válaszadók: 63,1\%-uk Magyarországon élő (321 fô), 36,9\%-uk pedig Romániai lakos (188 fő). Mindkét országban lévô kitöltők közül 203 fő $(39,9 \%)$ városban, 161 fó $(31,6 \%)$ faluban, 126 fó $(24,8 \%)$ megyeszékhelyen és 19 fó (3,7\%) fôvárosban él (1. táblázat).

A válaszadókat életkori kategória szerint az alábbi főbb csoportba sorolhatjuk:72,9\%-uk (371 fó) 19-25 év közötti, 13,8\%-uk (70 fö) 18 év alatti a többi kitöltő pedig 26- év feletti (168 fó). Az egy főre eső nettó jövedelem alapján két csoportra bontottuk az alanyokat, annak függvényében, hogy melyik országban élnek. Magyarországon az egy főre jutó nettó havi jövedelem kapcsán a leggyakoribb válasz a 101 000150000 ezer Ft közötti összeg volt (129 fő, (25,3\%), kicsivel lemaradva a $151000-250000$ Ft közötti 
kategória (94 fó, 18,5\%), majd ezeket követve a $100000 \mathrm{Ft}$ alatti (58 fó, 11,4\%), és a $250000 \mathrm{Ft}$ feletti (44 fö, 8,6\%).

Romániában az egy fơre jutó nettó havi jövedelem kapcsán a leggyakoribb válasz a 800-1400 lej, 58 fó (11,4\%), míg 1500-1900 lej között 47 fö (9,2\%), 20002400 lej között 35 fó $(6,9 \%), 2500$ lej felett 31 fó $(6,1 \%)$ és 800 lej alatt pedig 13 fö $(2,6 \%)$ keresett.

1. táblázat. A minta település típusa és ország szerinti megoszlása (Forrás: a Szerzőók)

\begin{tabular}{|c|c|c|c|}
\hline \multirow[b]{2}{*}{ Település típusa } & \multicolumn{2}{|c|}{ Melyik országban él? } & \multirow[b]{2}{*}{ Total } \\
\hline & $\begin{array}{c}\text { Magyarország } \\
\text { fö }(\%)\end{array}$ & $\begin{array}{c}\text { Románia } \\
\text { fö }(\%)\end{array}$ & \\
\hline \multirow{4}{*}{\begin{tabular}{|l|} 
Falu \\
Főváros \\
Megyeszékhely \\
Város \\
\end{tabular}} & $63(19,6)$ & $98(52,1)$ & $161(31,0)$ \\
\hline & $19(5,9)$ & $0(-)$ & $19(3,7)$ \\
\hline & $112(34,9)$ & $14(7,4)$ & $126(24,8)$ \\
\hline & $127(39,6)$ & $76(40,4)$ & $203(39,9)$ \\
\hline Total & $321(100)$ & $188(100)$ & $509(100)$ \\
\hline
\end{tabular}

\section{Eredmények}

A kitöltők 67,2\%-a (342 fô) végez testnevelés órán kívüli tevékenységet, melynek hossza minimum fél óra (2. táblázat).

2. táblázat. A válaszadók sportolási szokásai a megkérdezés alapján. (Forrás: a Szerzoók)

\begin{tabular}{|c|c|c|}
\hline \multirow{2}{*}{$\begin{array}{l}\text { Spottol-e? } \\
\text { (Igen= testnerevelés órán kírilil terééenrység, } \\
\text { egy alkalom hossza: minimum fél óra) }\end{array}$} & \multicolumn{2}{|c|}{ Melvik országban él? } \\
\hline & $\begin{array}{c}\text { Magyaroiszág } \\
\text { fo }(\%)\end{array}$ & $\begin{array}{c}\text { Románia } \\
\text { fo }(\%)\end{array}$ \\
\hline Igen & $227(70,7)$ & $115(61,2)$ \\
\hline Nem & $94(29,3)$ & $73(38,8)$ \\
\hline Total & $321(100)$ & $188(100)$ \\
\hline
\end{tabular}

Ez az érték jobb, mint amit a hazai mért adatokról korábban publikált az Eurobarométer 2018-as tanulmánya, mely szerint az Európai Unióban a lakosságnak csupán 7\%-a sportolt heti 5 vagy annál többször, 33\%uk heti 1-4 alkalommal, míg az ennél ritkábban sportolók aránya 14\% volt. 46\%-os volt azoknak a felnőtteknek az aránya, akik soha nem végeznek rendszeres sporttevékenységet (Eurobarometer, 2018).
Amennyiben összehasonlítjuk a romániai és a magyar válaszadók eredményeit, úgy megállapít-hatjuk, hogy a románok szignifikánsan kevesebbet sportolnak szabadidejükben, mint a magyar válaszadók. A magyarok 70,7\%-a, míg a román válaszadók csupán 61,2\%-a sportol (chi2 $=4,901, \mathrm{df}=1, \mathrm{p}=0,018)$ szabadidejében (3. táblázat).

3. táblázat. Mennyi idôt tölt átlagosan egy béten sportolással kérdésre adott válaszokból. (Forrás: a Szerző̉e)

\begin{tabular}{|c|c|c|c|}
\hline $\begin{array}{c}\text { Heti sportolási } \\
\text { gyakoriság }\end{array}$ & $\begin{array}{c}\text { Magyarország } \\
\mathrm{fo}^{\prime \prime}(\%)\end{array}$ & $\begin{array}{c}\text { Románia } \\
\mathrm{fo}^{\prime \prime}(\%)\end{array}$ & $\begin{array}{c}\text { Total } \\
\mathrm{fo}^{\prime \prime}(\%)\end{array}$ \\
\hline 2-3 óra & $95(29,6)$ & $40(21,3)$ & $135(26,5)$ \\
\hline $3-5$ óra & $70(21,8)$ & $28(14,9)$ & $98(19,3)$ \\
\hline 5-8 óra & $43(13,4)$ & $31(16,5)$ & $74(14,5)$ \\
\hline 8-10 óra & $29(9)$ & $18(9,0)$ & $47(9,2)$ \\
\hline Több mint 10 óra & $19(5,9)$ & $10(5,3)$ & $29(5,7)$ \\
\hline Nem sportol & $65(20,2)$ & $61(32,4)$ & $126(24,8)$ \\
\hline
\end{tabular}

Figyelembe véve azt is, hogy mennyit sétálnak, kocognak, kerékpároznak, a válaszadók 5,7\%-a (29fö) sportol több, mint 10 órát hetente, 9,2\%-a (47 fö) 8-10 órát, 14,5\%-a 5-8 órát (74 fó), 19,3\%-a (98 fö) 3-5 órát, 26,5\%-a (135 fö) pedig 2-3 órát sportol hetente. 24,8\%-uk (126 fő) azt válaszolta, hogy nem sportol, néha sétál, kerékpározik hetente, vagyis maximum 1 órát tölt el egy héten sportolással.

Amennyiben megnézzük a román és a magyar válaszadók sportolási gyakoriságát a chi2 próba alapján eltérnek a válaszok (chi2 $=14,05, \mathrm{df}=5, \mathrm{P}=0,015)$, a románok közül többen bizonyultak, akik inaktívnak (3. táblázat.).

A szabadidejüket az emberek leginkább passzív szabadidôs tevékenységekkel töltik. Nagyon népszerú a média világa, amit bizonyít a kutatásunk is, hiszen a válaszadók $68 \%$-a a szabadidejét internetezéssel (számítógép, mobil, tablet) tölti.

A második legnépszerúbb időtöltés is a passzív pihenés kategóriájába tartozik, hiszen 63,3\%-uk Tvnézéssel vagy zenehallgatással próbálja kipihenni a fáradalmakat és próbál újra feltöltődni. 51,7\%-a az embereknek szereti passzív pihenéssel, lustálkodással az ágyban eltölteni az idejét. A kutatás egybevág más hazai kutatási eredményekkel, ahol a fiatal felnôttek 
mintájában szintén a passzív szabadidős tevékenységek domináltak (Müller et al., 2011, Mosonyi et al., 2013, Boda et al., 2015, Boda et al., 2019, Laoues et al., 2019) . Ezek után következik az aktív szabadidő eltöltés, a válaszadók 47,42\%-a szabadidejükben sportol. Népszerű szabadidő eltöltés még az olvasás vagy meditáció 41,5\%, a házimunka (takarí-tás, főzés, mosás, kukaürítés, kertészkedés stb.) 37,1\%, háziállattal való sétálás, játszás 32,8\%, a tanulás $26,9 \%$, a vásárlás 22,8\%, míg kevésbé népszerú a sporteseményeken való részvétel szurkolóként 20,2\%, a vallásos tevékenységek (templomba járás, egyházmegyei programokon való részvétel, hittanóra stb.) 16,5\%; egészségmegőrzés (szauna, fürdő) 13,4\%; muzsikálás $9,4 \%$; horgászat $4,9 \%$; vadászat $1 \%$. A meditáció és spiritualitás felértékelődését és keresletének növekedését erôsíti meg több kutatás (Lengyel, 2016, 2019).

A válaszadók nem minden esetben ugyanazokat a szabadidős tevékenységeket végzik, több választ is jelölhettek, így jöttek ki ezek a százalékos arányok. Ezekből a számadatokból elmondható, hogy bár az emberek 94,9\%-a ülő munkát végez vagy mindkettőt (ülő és fizikai munkát is), mégis kevés időt töltenek aktívabb szabadidős tevékenységekkel. Érthető, hogy aki fizikai munkát végez, az szabadidejében inkább olvas, pihen vagy zenét hallgat.

\section{Hol sportol?}

Románok között kevesebben vannak, akik fitneszwellness központban sportolnak (12,8\%) és hajlandóak fizetni szolgáltatásért, mint a magyar válaszadók $(22,7 \%)$, melyet a chi2 próba igazolt (chi2 $=11,2, \mathrm{df}=5$, $\mathrm{p}=0,046$ ) (4. táblázat). A válaszadók 90,4\%-a (460fő) tisztában van a környezetében található sportolási lehetőségekkel (egyesület, kondipark, edzőtermek, stb.), mégis keve-sen járnak el ilyen helyekre. A legnépszerúbb sportok, amelyeket manapság az emberek szívesen űznek az a fitness (Gödény et al., 2018, Müller et al., 2019b), a futás, az úszás, a zumba, az aerobik, a futball (Bácsné et al., 2018b; Balogh et al., 2019) míg kevésbé népszerūek a kosárlabda, a tenisz, a kézilabda. Ezeket az állításokat támasztja alá az elvégzett kutatásunk is. Az emberek közül a legtöbben inkább gyalogolnak, túráznak, nordic-walkingoznak, futnak, kerékpároznak vagy fitness edzésekre járnak. Legkevésbé népszerú sport a kitöltők között a jégkorong, a golf, a sakk, az íjászat, a tenisz, a vívás. Észrevehető, hogy azok a sportok népszerúbbek, amelyeket az emberek a természetben, szabad levegőn vagy éppen iskolába/egyetemre/munkába menet végezhetnek. A természeti sportok szintén fontos szerepet játszanak a képességfejlesztésben és a stressz oldásban is (Borbély és Müller, 2015).

4. táblázat. A szabadidö eltöltésének formái. (Forrás: a Szerzök

\begin{tabular}{|l|c|c|}
\hline \multicolumn{1}{|c|}{ Mivel tölti legszívesebben a szabadidejét? } & Fő & Százalék (\%) \\
\hline Passzív pihenés, lustálkodás az, ágyban & 263 & 51,7 \\
\hline Tv nézés vagy zenehallgatás & 322 & 63,3 \\
\hline Olvasás vagy meditáció & 211 & 41,5 \\
\hline Egészségmegőrzés (szauna, fürdő) & 68 & 13,4 \\
\hline Vásárlás & 116 & 22,8 \\
\hline Horgászat & 25 & 4,9 \\
\hline Vadászat & 5 & 1 \\
\hline Valamilyen sportolás, mint például kerékpározás, úszás, futás vagy egyéb & 240 & 47,2 \\
\hline Tanulás & 137 & 26,9 \\
\hline Muzsikálás & 48 & 9,4 \\
\hline Internetezés (számítógép, telefon stb.) & 346 & 68 \\
\hline Házimunka (takarítás, főzés, mosás, kukaürítés stb.) & 189 & 37,1 \\
\hline $\begin{array}{l}\text { Vallásos tevékenység (templomba járás, egyházmegyei programokon való } \\
\text { részvétel, hittanóra stb.) }\end{array}$ & 84 & 16,5 \\
\hline Sporteseményen való részvétel szurkolóként & 103 & 20,2 \\
\hline Háziállattal való sétálás, játszás & 167 & 32,8 \\
\hline Egyéb & 51 & 10 \\
\hline
\end{tabular}


A válaszadók 20\%-a otthon szokott sportolni, bizonyára, mivel nem szeretnek kimozdulni, emellett ez költséghatékony módszer is egyben. 19,8\%-a a kitöltóknek a szabadban parkokban szereti elvégezni a testmozgást. Ők ilyenkor átadhatják magukat a természetnek és jobban kikapcsolódnak. Mivel a népszerú sportágak közé tartozik a fitness, így egyértelmú, hogy sokan a fitness-wellness közpon-tokban sportolnak. Több személy azért nem sportol, mert nincs rá szabadideje, ennélfogva sokan iskolába/munkába/egyetemre menet sportolnak. Egyesületben az emberek 14,5\%-a sportol.

A válaszadók leginkább abból a célból szoktak sportolni, hogy fenntartsák az egészségüket és a jó közérzetüket (231 fö), ugyanakkor a sport boldoggá teszi óket (197 fö), továbbá azért, hogy fogyjanak, javítsanak a külső megjelenésükön (189 fô), de az izgalmas, szórakoztató jelleget is sokan jelölték (148 fö). A külső tényezők, vagyis, azért mert mások elvárják tôlük, nagyon kevesen sportolnak (15 fó).

Nagyon fontos a sporthoz a megfelelő motiváció jelenléte (Fyodorov et al. 2019, BendíkováDobay 2017). Sokan motiválatlanság miatt nem sportolnak. Megkérdeztük a válaszadókat, hogy őket ki motiválta arra, hogy elkezdjenek sportolni. 424 fő $(83,5 \%)$ saját elhatározásából kezdett el sportolni. A barátok 151 fôt $(29,7 \%)$ buzdítottak a sportra, míg a szülők 126 fő́t (24,8\%). Testvér, tanár, edző, orvos kevés embert motiváltak a sportra (1. ábra).

Meglátásunk szerint mindenképpen ösztönözni növelni kellene azt, hogy a szülők motiválják a gyerekeket a sportra, hiszen a család vagy szüló meghatározó szerepéről több kutatás ír (Laoues 2017, Mező és Mező 2017, Herpainé 2018, KőnigGörögh 2019). Véleményünk szerint minél több szülő végezne aktív testmozgást, annál több gyermek kapcsolódna be a sport világába. Mivel a kitöltők döntő része (97,1\%-a) tisztában vannak a sport pozitív hatásaival (97,1\%-uk), bizonyára emiatt válaszolták azt, hogy ha van vagy majd ha lesz gyermekük, akkor támogatni fogja abban, hogy sportoljon (99,4\%-uk). 379 fó azt állítja, hogy van lehetősége arra, hogy azt sportolja, amit szeret. 101 fő pedig azt, hogy lenne lehetősége, de nincs elég szabadideje az aktív testmozgás elvégzésére. 51 személyt pedig az anyagi javai nem engedik, hogy olyan sportot ûzzön, amit szeretne. A válaszadók többsége egyedül szeret sportolni (323 fó, 63,6\%). Barát/barátnővel 250 fó, (49,2\%), csapatban 214 fó $(42,1 \%)$ végzi szívesebben az aktív testmozgást. Egyesületben, edzővel relatíve kevesen szeretnek együtt sportolni. Ez bizonyára abból adódhat, mivel több edzőnek még nem sikerült szoros kapcsolatot kialakítania a versenyzőivel.

1. ábra. A sport iránti motivációt befolyásoló személy. (Forrás: a Szerzóke)

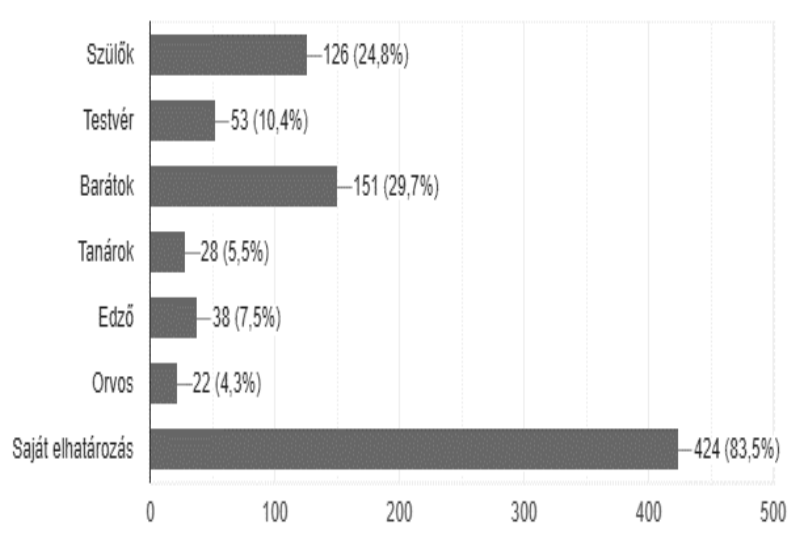

Jól vitatható téma, hogy az ember egyedül vagy csoportban sportoljon. Mindkettőnek vannak előnyei és hátrányai is. Akik egyedül szeretnek sportolni azok, szeretnek kiszakadni a sport által a mindennapokból, elmerülnek saját gondolataikban. Ezek az emberek saját maguknak állitják össze az edzéstervüket, azokat a gyakorlatokat végzik, amelyeket ők jobban szeretnek, nem kell alkalmazkodjanak más emberekhez. Az egyedül sportoló 
embereket nincs aki ösztönözze az edzésre, így náluk észrevehetô, hogy néha elmarad az edzés lustaságból, motiválatlanságból. A társas emberek jobban szeretnek csoportosan edzeni. Az egyik előnye a csoportos sportnak, hogy csökkentheti a stressz-szintet. Együtt izzadni, együtt fáradni, együtt leküzdeni az edzés nehézségeit mégis csak valahogy könnyebb, mint egyedül. Motiválhatjuk a másikat, vagy motiválhatnak minket is arra, hogy jobban hajtsunk, ha észrevesszük, hogy valaki gyorsabb, ügyesebb, mint mi és nem szeretnénk lemaradni a másiktól. Egy jó társaságban jobban repül az idő, szinte észre sem vesszük, hogy már egy órája sportolunk, vagy akár két óra is elrepülhet úgy, hogy fel sem tûnik. Vannak olyan esetek, amikor bizonyos személyek csak az edzésen találkoznak, elôtte, utána beszélgethetnek, így egy ilyen rendszer az életünkben áldásos lehet, mivel tudjuk, hogy egy héten egyszer-kétszer ott találkozhatunk a számunkra fontos személlyel. Az edzés alatt két személy sokkal szorosabbra füzheti a kapcsolatát, mivel látják egymást erőlködni, küzdeni, bíztathatják, támogat-hatják egymást.

A motiváció a sportban elengedhetetlen, hiszen minden olyan tényezőre hatással van, amely befolyásolja a teljesítményt: fizikai erőnlét, technikai és taktikai edzés, mentális felkészülés, valamint a mindennapi életstílus is ide tartozik.

A fontosságának oka pedig nem más, mint hogy ez az egyetlen olyan tényező, amelyet saját magunk kontrollálni tudunk. Magas motiváció esetén idôt és energiát fektetünk a sportolásba, hogy még magasabb szintekre emelhessük az edzettségi fokunkat vagy a játék színvonalát. Viszont vannak napok, amikor a legkevésbé sincsen kedvünk edzőterembe, futni vagy a már elöre megbeszélt edzésre menni. Ilyenkor jó, ha van egy edzôtársunk, aki segít kilépni a komfortzónánkból, és rá tud minket venni a mozgásra. Hátrányként felsorolható, hogy a csoportos edzés nem egyénre szabott, nem igazodik a saját ritmusunkhoz, edzettségi szintünkhöz, éppen ezért kevésbé lehet eredményes. Ilyenkor alkalmazkodni kell más személyekhez, idôponthoz stb. Néhány esetben negatív hatással lehetnek ránk mások, miattuk mi sem edzünk hosszabb ideig, nem figyelünk oda a gyakorlatok helyes elvégzésére stb., ezért fontos, hogy olyan csoporttal eddzünk, akik pozitívan hatnak ránk az edzés során.

Mindenki el kell, hogy döntse saját magában, hogy ő hogyan szeretne jobban sportolni. Ha egyedül, akkor fontos, hogy legyen elég motivációja, kitartása az edzésekhez. Ha csoportosan, akkor pedig meg kell találni a megfelelő személyeket a közös edzéshez, akik pozitív hatással lesznek ránk. Az emberek többsége megtalálta azt a személyt, akivel szívesen edzene együtt, mivel 78,2\%-uk a válaszadóknak azt a választ adta, hogy van olyan személy a környezetében, aki megkérhetne, hogy motiválja ôt a sportra, vagy ha elhívná sportolni, akkor szívesen társulna hozzá. A fennmaradó 21,8\%-uk számára a csoportos edzések hozhatnának változást. Ha részt vennének valamilyen csoportos edzésen, akkor biztosan lenne ott más olyan személy, akivel összebarátkozna, később pedig motiválhatnák egymást. Ha mégsem lenne ilyen személy, akkor pedig az ottani edzővel lehet kialakítani ilyen kapcsolatot és ő az edzéseken motiváló szerepet fog betölteni az egyén életében. Elsősorban azért nem sportolnak az emberek, mivel nincs elég szabadidejük. Többen azt állítják, hogy többet sportolnának, ha lenne olyan személy, aki motiválja őket, ha találna egy olyan egyesületet, közösséget, ahol jól érzi magát.

$\mathrm{Ha}$ az egyetem/iskola/munkahely rendezne különböző sportnapokat, akkor az emberek 78,6\%a részt venne rajta. Szerintük ezek a rendezvények jó szórakozási lehetőségek lennének, erősítené a kapcsolatokat, segítene a kikapcsolódásban, jobbá válna a közösség, egészségesebbek lennének az emberek, felöltődnének. Hatásos módszer lenne, hogy a különböző vállalatok minél több sportnapot tartanának, ahol megmozgatnák az alkalmazottakat, mellyel pozitív hatást érnének el, mivel az emberek sokkal aktívabban végeznék a munkájukat 
ugyanannyi idő alatt (Hidvégi et al., 2017). Az emberek 89\%-a szerint jobb lenne az emberek teljesítménye a munkahelyen /iskolában/ egyetemen, ha a munka, tanulás közben lenne valamilyen sporttal kapcsolatos tevékenység is (mint például, a 8 óra munkából 30 perc vagy 1 óra állna rendelkezésükre, hogy részt vegyenek egy tornán, ritmikus gimnasztikán, valamilyen mozgásos tevékenységen vagy az iskolában/egyetemen is lenne olyan 30 perc, amikor többet mozoghatnának). Meglátásunk szerint azért válaszolhatták ezt a megkérdezettek, mivel akik sportoltak már azok sportolás után felfrissültebbnek érezték magukat, jobb volt a hangulatuk, pozitívabban gondolkodtak, sport után sokkal hatékonyabb volt a tanulás, jobban tudtak összpontosítani az előttük álló feladatokra (2. ábra).

\section{2. ábra. Pozitív változás sport után. (Forrás: a Szeraōk) 509 válasz}

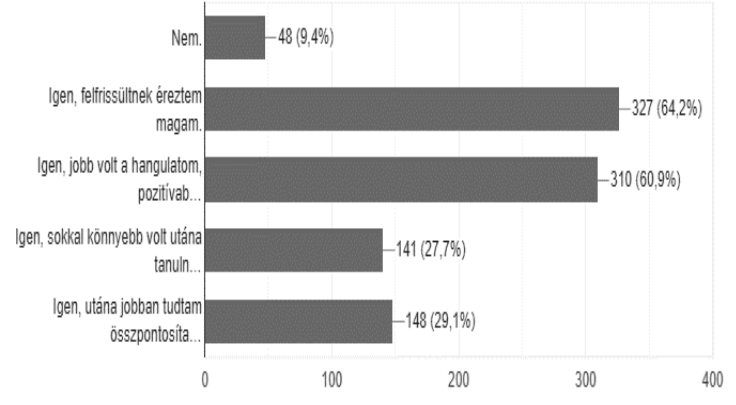

Továbbá a válaszadók szerint azok akik sportolnak egészsé-gesebbek, jobb hangulatúak, csinosabbak, összeszedettek, jobban tudnak teljesíteni a munkájukban és jobban be tudják osztani az idejüket.

Szintén kíváncsiak voltunk arra, hogy szoktak-e követni valamilyen sportot a televízióban, interneten, rádióban vagy élőben a kitöltők, továbbá, hogy hozzájárultak-e ezek ahhoz, hogy elkezdjenek sportolni vagy motiválják-e őket ezek. A válaszadók 39,7\%-a nem követ semmilyen sportot, sportese- ményt. 33,2\%-uk számára motiválók ezek az események és nagy figyelemmel követik őket. 28,1\%-uk pedig követi ezeket az eseményeket, de nem buzdította őket a sportra.

\section{Konklúziók}

A nemzetközi és hazai tanulmányokhoz hasonlóan kutatásunk is megerősítette, hogy az emberek többsége ülő munkát végez, melyhez arányosan kevesebb sporttal és fizikai aktivitással eltöltött idő társul. A vizsgált magyar és román minta alapján a megkérdezettek szabadidejüket jellemzően olyan tevékenységekkel töltik, melyek passzív szabadidős tevékenységek. Ezeknek az embereknek több időt kellene szánni az aktív szabadidős tevékenységekre (Bíró-Müller, 2017). A fizikai aktivitás és sportolás ösztönzése a munkahelyeken is fontos, mivel egészségesebb és teherbíróbb munkaerőt jelentve a termelékenység növekedéséhez is képes hozzájárulni. A testnevelési és sportprogramok ösztönzését (Hidvégi et al., 2017) emeli ki több szerző, mivel a sport elősegíti a kikapcsolódást, a felfrissülést, a jobb közérzetet biztosít ezért segít javítani az emberek közérzetén, csökkenti a stressz szintet és prevenciós eszközként funkcionál számos életmódfüggő betegség esetében.

\section{Támogató}

A publikáció elkészítését az EFOP-3.6.2-162017-00003 számú projekt támogatta. A projekt az Európai Unió támogatásával, az Európai Szociális Alap társfinanszírozásával valósult meg.

\section{Irodalom}

Bácsné Bába, É. ,Fenyves, V.. Dajnoki K., Szabados, Gy. (2018a): Sportszolgáltatások kínálatának elemzése szervezeti szempontok alapján. International Journal of Engineering and Management 
Sciences / Müszaki és Menedzsment Tudományi Közlemények 3.: 4.465-474.

Bácsné Bába, É., Fenyves, V. ,Szabados, Gy.. Pető, K., Bács, Z., Dajnoki, K. (2018b): Sport Involvement Analysis in Hungary, in the North Great Plain Region. Sustainability 10:(5) DOI:10.3390/su10051629

Balogh, R., Dajnoki, K., Bácsné, Bába É. (2019): Miért beteg a magyar futball még mindig? - a magyar labdarúgás játékos piacának jellemzése. Jelenkori Társadalmi és Gazdasági Folyamatok 13 : 3-4. 105-117.

Bendíková E., Dobay B. (2017): Physical and sport education as a tool for development of a positive attitude toward health and physical activity in adulthood. European Journal of Contemporary Education, 6 (1), 14-21

Bendíková, E., Marko, M. Müller A., Bába É. Bácsné (2018): Effect of Applied HealthOriented Exercises in Physical and Sport Education on Musculoskeletal System of Female Students. Acta Facultatis Educationis Physicae Universitatis Comenianae 58: 2 . 84-96.

Bíró M. (2018): Bevezetés a sportpedagógiába In: Münnich, Ákos (szerk.) Fejezetek a Sportpszichodiagnosztike és Tanácsadás témaköreiböl. Debrecen, Magyarország: Debreceni Egyetem Bölcsészettudományi Kar Pszichológiai Intézet.

Bíró, M.. Müller, A. (2017): Aktív pihenés, rekreáció $=$ Active relaxation, recreation. In: Dobos, Anna; Mika, János (szerk.) Természeti és kultúrtörténeti értékek Eger térségében $=$ Natural and cultural heritage in the Eger Region. Eger, Líceum Kiadó, 128-130.

Boda, E., Honfi, L., Bíró, M., Révész, L., Müller, A. (2015): A szabadidő eltöltésének és a rekreációs tevékenységek vizsgálata egri lakosok körében Acta Academiae Paedagogicae Agriensis Nova Series: sectio sport. 49-62.

Boda, E. J., Bácsné, Bába É., Laoues-Czimbalmos, N., Müller, A. (2019). Rekreációs fogyasztói szokások vizsgálata magyar fiatal felnőttek körében, Különleges Bánásmód 5 : 4 33-44.

Borbély, A., Müller, A. (2015): Sport és turižmus, Debrecen, Magyarország: Campus Kiadó.

Buda B. (1994): A sportmentálhigiéné koncepciója. Mentálhigiéné. Tanulmánygyüjtemény. Animula Budapest 257-284.

Dajnoki, K.. Héder, M. (2017): „Új szelek fújnak” - a HR válasza a globalizáció és a változás kihívásaira. Hadtudomány, 27: E-szám. 84-93.

Dajnoki, K., Szabados, Gy. N., Bácsné, Bába É. (2018): A Case Study on Human Resource Management Practice of a Sport Organization. International Journal of Engineering and Management Sciences 3: 4 . 410-425.

Dajnoki, K. (2012): Esélyegyenlőség és diszkrimináció - Fogyatékos és megváltozott munkaképességű személyek a munka világában. Közép-Európai Közlemények V. évf.: 1. sz. 145-156.

Dajnoki, K. (2014a): "Aki keres az talál" - Fogyatékos emberek által betöltött munkakörök feltárása. Acta Scientiarum Socialium 40.101-110.

Dajnoki, K. (2014b): HR sajátosságok feltárása vezetői mélyinterjúk alapján megváltozott munkaképességú személyeket foglalkoztató szervezeteknél. Közép-Európai Közlemények. VII. évf.: 26-27.. 185-195.

Dobay B., Müller A., E. Bendíková (2017): Adult Health in Terms of Selected Lifestyle Factor. Disputationes Scientificae Universitatis Chatholicae In Ruzomberok 17: 4. 32-39.

Eurobarometer, 2018 Special Eurobarometer 472, Sport and physical activity, https://www.loketgezondleven.nl/sites/default Lfiles/201812/Eurobarometer 472_PhysActivS ports2018.pdf

Fenyves, V., Dajnoki, K., Bácsné, Bába É. (2018): Assessment of sport activites among higher education students in Eastern Europe. Sea: Practical Application of Science VI: 3 . 347-353.

Fenyves, V., Dajnoki, K., Bácsné, Bába É. (2019b): Sportolási szokások vizsgálata a Campus Sport- 
fesztivál tapasztalatai alapján. Acta Carolus Robertus 9: 2. 27-40.

Fenyves, V., Dajnoki, K., Kerezsi, D., Bácsné, Bába É. (2019a): Analysis of Sport Motivation Factors amongst Eastern European Higher Education Students. European Journal Of Contemporary Education 8: 4. 761-778.

Fyodorov, A. I., Erlikh, V. V., Khafizova, A., Bendikova, E. (2019): Young students' health attitudes. Journal of Physical Education and Sport, 19 (4), 2512-2517.

Gődény N., Biró M., Lenténé P. A., Lente L. \& Müller A. (2018): A fogyasztói szokások és trendek változásának vizsgálata a fitnesz területén. In Balogh, László (szerk.) Fókusz̧ban az. egészség. Debreceni Egyetem Sporttudományi Koordonációs Intézet, Debrece. 9-18.

Héder, M. ,Szabó, Sz. ,Dajnoki, K. (2018): Effect of Labour Market Changes on HR Functions. Anali Ekonomski Fakulteta U Subotici / The Annals of the Faculty of Economics Subotica 54: 39. 123-138.

Herpainé L, J. (2018): Three generation research concerning sport and value. In: Jaromír, Šimonek; Beáta, Dobay (szerk.) Sport science in motion: proceedings from the scientific conference. Komárno, Szlovákia : Univerzita J. Selyeho, 274-280.

Hidvégi, P., Bíró, M., Müller, A.,Váczi, P. (2017): Testnevelési program a munkahelyi egészségfejlesztésben, Acta Academiae Paedagogicae Agriensis Nova Series: Sectio Sport 44. 115-138.

Horkay B. ,Lenténé- - Puskás A., Biró M. (2018a): The supply elements and the recreational possibilities in the city and in the countryside In: Jaromír, Šimonek; Beáta, Dobay (szerk.) Sport science in motion: proceedings from the scientific conference. Komárno, Szlovákia: Univerzita J. Selyeho. 330339.

Horkay B., Lenténé-, Puskás A., Bíró M. (2018b): A város és vidék kinálati elemeinek és szabadidôs lehetöségeinek összehasonlitása egy viæsgálat tükrében. In:
Balogh, László (szerk.) Fókuszban az egészség. Debrecen, Magyarország: Debreceni Egyetem Sporttudományi Koordinációs Intézet, 94-105.

Juhász I., Kopkáné Plachy J. Kiszela K., Bíró M., Müller A., \& Révész L. (2015): Időskorúak rekreációs fizikai aktivitásának hatása a kardiorespiratorikus rendszerre. Magyar Sporttudományi Szemle 16: 63. 4-8.

Kőnig-Görögh, D., Szerdahelyi, Z., CzimbalmosLaoues, N., Olvasztóné, Balogh Zs. (2019):4-6 éves korú magyar óvodások testi fejlődésének és motorikus szintjének összehasonlító elemzése. In: Pálfi, Sándor (szerk.) Kora gyermekekori nevelés, család és közösségek = Early childhood education, families and communities. Debrecen, Didakt Kft., 95-107.

Laoues-, Czimbalmos N., Dobay, B.,Müller, A., Examination of the Leisure Time-Related Consumption Habits of Young People With Disabilities with Special Emphasis on Sports, Selye EStudies $10: 2.34-45$.

Lengyel, A. (2016): Tourism, meditation, sustainability. Apstract - Applied Studies in Agribusiness and Commerce 10: 1. 81-92.

Lengyel, A. (2019): A mindfulness és liminalitás felértékelődése: spirituális elvonulási központok, a fenntartható jövő desztinációi? Turiżus Bulletin 19: 1. 14-24.

Lenténé-, Puskás A., Biró M., Dobay B., Pucsok J. M. (2018): A szabadidó sportolás kinálati elemeinek, és szolgáltatásainak viæsgálata Magyarország Észak-alföldi régiojának szállodáiban. Selye estudies 9:1. 13-21.

Mező, F., Mező, K. (2017): A szülők nevelési stílusa és hatásuk a gyermekek magatartására: a családból való kimenekülés pedagógiai okai. In: Vargáné, Nagy Anikó (szerk.) Családi nevelés 2. Debrecen, Magyarország: Didakt Kft.,. 5066.

Mosonyi, A., Könyves, E., Fodor, I., Müller, A., Leisure activities and travel habits of College students in the light of a survey. Apstract - App- 
lied Studies in agribusiness and Commerce $7: 1.57$ 61.

Murányi I. (2010): Egyetemisták szabadidős tevékenysége és mentális sátusa. Educatio 2010/203-213.

Müller A., Bácsné Bába É. (2018): Az egészséges életmód és a sport kapcsolata. Létavértes, Magyarország: Létavértes SC '97 Egyesület.

Müller A., Lengyel A., Koroknay Zs., \& Molnár A. (2019b): Népszerú fitnesz mozgásformák. In: Bácsné Bába É., \& Müller A. (szerk.) "Mozgással az egéssségért" A firikai aktivitás jelentösége a jövo" munkavállalóinak egészségmegörrésében : Nemzetközi
Konferencia és Workshop: Válogatott tanulmánykötet $=$ Debrecen, Magyarország: Debreceni Egyetem, 106-112.

Müller, A., Kerényi, E., Könyves, E. (2011): Effect of climate therapy and rehabilitation in Mátra Medical Institute Applied Studies in Agribusiness and Commerce, Apstract - Applied Studies In Agribusiness and Commerce 5: 3-4 39-42.

Simon I. Á., Kajtár G., Herpainé Lakó J., \& Müller A. (2018): A fizikai aktivitás és a mentális egészség jelentősége a 60 év fölötti korosztály életében. Képzés és Gyakorlat: Training And Practice 16: 1. 25-36. 